\title{
Postharvest quality and functional compounds in "dedo-de-moça" 'BRS Mari' pepper fruit at different stages of maturity
}

\author{
Qualidade pós-colheita e compostos funcionais de pimenta dedo-de-moça \\ 'BRS Mari' em diferentes estádios de maturação
}

\author{
Cristina Soethe $^{\mathrm{I}^{*}}$ Cristiano André Steffens ${ }^{\mathrm{I}}$ Leonora Mansur Mattos ${ }^{\mathrm{II}}$ \\ Nathalie Alcântara Ferreira ${ }^{\mathrm{III}}$ Daiane Michele Mayer $^{\mathrm{IV}}$
}

\section{ABSTRACT}

The purpose of this study was to evaluate the physicochemical characteristics and functional properties of "dedo-de-moça" 'BRS Mari' pepper fruits at different maturity stages, and determine the ideal harvest stage for fresh consumption. The pepper plants were grown in the experimental field of Embrapa Hortaliças (Brasília, DF, Brazil) in 2012, and their fruits were evaluated at 20,30, 40, 50, 60, 70, and 80 days after anthesis (DAA) to determine the soluble solid content (SS), titratable acidity (TA), SS/TA ratio, color (hue angle and lightness), $a, b$, and total chlorophyll, total phenolic compounds (TPC), total antioxidant activity (TAA), and capsanthin. It was observed that SS content increased until $70 D A A$, and TA increased until $50 \mathrm{DAA}$, with decrease at $80 \mathrm{DAA}$. The a and total chlorophyll decreased until 60 DAA. Values for chlorophyll $b$ were high until $30 \mathrm{DAA}$, and then decreased. The values for hue angle and lightness decreased until $60 \mathrm{DAA}$, indicating a change from green to red in fruits external color, with small changes in color from 60 to $80 \mathrm{DAA}$. The TPC content increased until $60 \mathrm{DAA}$, and then small increases occurred until $80 D A A$. The AA increased as the fruit ripened, and the capsanthin content increased until 70 $D A A$. These results indicated that the ideal stage for harvest of the "dedo-de-moça" 'BRS Mari' pepper fruits is at 70 days after anthesis, when they also have a full development of red color in the fruit epidermis.

Key words: Capsicum baccatum var. pendulum, maturing, physicochemical composition, antioxidant activity.

\section{RESUMO}

$O$ objetivo deste trabalho foi avaliar as características físico-químicas e propriedades funcionais da pimenta dedo-de-moça 'BRS Mari', em diferentes estádios de maturação, e determinar o estádio ideal de colheita dos frutos destinados ao consumo in natura. As pimentas foram cultivadas no campo experimental da Embrapa Hortaliças (Brasilia, DF, Brasil), em 2012. Seus frutos avaliados aos 20, 30, 40, 50, 60, 70 e 80 dias após a antese (DAA) quanto ao teor de sólidos solúveis (SS), acidez titulável (AT), relação $S S / A T$, coloração (ângulo hue e luminosidade), clorofilas $a, b$ e total, compostos fenólicos totais (CFT), atividade antioxidante (AAT) e capsantina. Observou-se que o teor de SS aumentou até $70 \mathrm{DAA}$ e a AT aumentou até os $50 \mathrm{DAA}$ com decréscimo aos 80 DAA. Clorofilas a e total diminuiram até $60 \mathrm{DAA}$. Os valores de clorofila $b$ foram mais elevados até $30 \mathrm{DAA}$ e depois diminuíram. Os valores de ângulo hue e luminosidade diminuíram até $60 \mathrm{DAA}$, indicando mudança de verde para vermelho na 'coloração externa' dos frutos, com pequenas mudanças na coloração de 60 até $80 \mathrm{DAA}$. $O$ conteúdo CFT aumentou até 60 DAA e depois pequenos aumentos ocorreram até $80 \mathrm{DAA}$. AAT aumentou à medida que os frutos amadureciam e conteúdo de capsantina aumentou até $70 \mathrm{DAA}$. Esses resultados indicam que o estádio ideal para colheita da pimenta dedo-de-moça 'BRS Mari'é aos 70 dias após a antese, quando ela também apresenta o total desenvolvimento da coloração vermelha na epiderme.

Palavras-chave: Capsicum baccatum var. pendulum, maturidade, composição físico-química, atividade antioxidante.

\section{INTRODUCTION}

Fruits and vegetables are important foods in the human diet, due to the presence of

ICentro de Ciência Agroveterinárias, Universidade do Estado de Santa Catarina (UDESC), Av. Luiz de Camões, 2090, Conta Dinheiro, 88520-000, Lages, SC, Brasil. E-mail: crisoethe@gmail.com. *Autor para correspondência.

IIEmbrapa Hortaliças, Brasília, DF, Brasil.

IIIUniversidade de Brasília (UnB), Campus Universitário Darcy Ribeiro, Brasília, DF, Brasil.

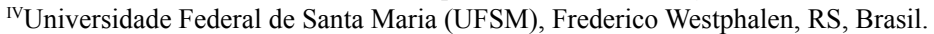


bioactive compounds and antioxidant-active substances, which exert a protective function in the body. Peppers of the gender Capsicum are excellent sources of natural antioxidants, such as carotenoids and phenolic compounds (NADEEM et al., 2011). Among the pepper species, Capsicum baccatum var. pendulum (commonly known as "dedo-de-moça", "finger-of-young-lady", much used in cooking worldwide) is highlighted (FERRÃO et al., 2011).

During ripening of its fruit, they undergo several changes in color. The green color of the fruit is mainly due to the presence of chlorophyll, which is degraded during maturation, whereas carotenoids (responsible for the yellow, orange, and red colors) are synthesized. Capsanthin, capsorubin, cryptoxanthin, and zeaxanthin are the major carotenoids present in Capsicum (NADEEM et al., 2011). Capsanthin is found in a higher concentration in red (mature) fruits (GUZMAN et al., 2010), and represents more than $50 \%$ of the total carotenoids present in ripe fruits (PINTO et al., 2013).

The Capsicum species also have in their chemical composition significant levels of phenolic compounds and secondary metabolites, which are synthesized by plants as a response to stress conditions (NADEEM et al., 2011). Stress levels vary during fruit ripening, and contribute to the fruit sensory characteristics such as color, astringency, bitterness, and flavor (RODRÍGUEZMATURINO et al., 2012).

Typically, Capsicum fruit maturity is assessed according to its visual characteristics, such as color and size. However, a more accurate assessment of the exact time to harvest the fruit can be carried out by taking into account the period from the beginning to the maximum opening of the flower, known as anthesis (CAVALCANTE et al., 2009).

The purpose of this study was to assess the physicochemical characteristics and functional properties of the "dedo-de-moça" 'BRS Mari' pepper fruit in different maturity stages and determine the ideal stage to harvest the fruits for fresh consumption.

\section{MATERIALS AND METHODS}

The "dedo-de-moça" 'BRS Mari' pepper plants were grown in the experimental field of Embrapa Hortaliças (Brasília, DF, Brazil), in 2012. Flowers were marked at anthesis, about 105 days after the seedlings were transplanted. Fruits were collected manually and randomly at 20, 30, 40, 50, 60, 70, and 80 days after anthesis (DAA). A completely randomized experimental design was used, with three replications, and the experimental unit was composed of 50 fruits. After harvest, the fruits were taken to the Laboratory of Science and Food Technology at Embrapa Hortaliças and analyzed for soluble solid content (SS), titratable acidity (TA), SS/TA ratio, color (hue angle and lightness), $a, b$, and total chlorophyll, total phenolic compounds (TPC), total antioxidant activity (TAA), and capsanthin.

The TA, SS, color, chlorophyll, and capsanthin were analyzed as described by MATTOS et al. (2007). The TA values (\% citric acid) were obtained from fresh tissue $(10 \mathrm{~g})$, diluted in distilled water $(90 \mathrm{~mL})$, and titrated with $\mathrm{NaOH}$ $(0.1 \mathrm{~N})$ to $\mathrm{pH}$ 8.2. The SS ( $\left.{ }^{\circ} \mathrm{Brix}\right)$ were determined in a digital refractometer (Atago ${ }^{\circledR}$, PR201 $\alpha$ model; Tokyo, Japan). The SS/TA ratio was calculated dividing the SS values by those of AT. The skin color was determined in terms of hue angle and lightness by using a colorimeter (Konica Minolta ${ }^{\circledR}$, model CR 400; Tokyo, Japan). The total, $a$, and $b$ chlorophyll contents were determined using $\mathrm{N}$, $\mathrm{N}$-dimethylformamide (DMF) as solvent. The absorbance values were read on a UV-visible spectrophotometer (HITACHI, model U-1100; Japan) in two wavelengths (647 and $664.5 \mathrm{~nm}$ ). The capsanthin content was determined in dry samples $(0.5 \mathrm{~g})$ mixed with acetone (P.A.; $100 \mathrm{~mL})$. The absorbance were read on a UV-visible spectrophotometer $(\lambda=460 \mathrm{~nm})$.

To obtain the extracts for analysis, the sample $(5.0 \mathrm{~g})$ was homogenized in methanol (P.A.; $10 \mathrm{~mL})$. The homogenate was then submitted to agitation (shaker; 60min) and centrifuged (Sorvall, RC 6 Plus; DE; 15,000rpm; 5min). After filtration, the supernatant was left aside for determination of TPC content and TAA.

Determination of TPC content was determined using the Folin-Ciocalteu reagent, as described by ROESLER et al. (2007), with some modifications. The standard curve of gallic acid was obtained using different concentrations $(0$, $10,30,50,70,90$, and $100 \mathrm{ppm})$. For analysis of the samples $(0.5 \mathrm{~mL})$, Folin-Ciocalteu reagent $(2.5 \mathrm{~mL} ; 1: 3)$ and sodium carbonate solution $(10 \%$; $2.0 \mathrm{~mL})$ were added. The tubes were stirred in a vortex mixer, incubated (1h; protected from light) and the samples were centrifuged. Absorbances were read on a UV-visible spectrophotometer $(\lambda=765 \mathrm{~nm})$. Results were expressed in terms of 
mg of gallic acid equivalents per $100 \mathrm{~g}$ of sample $\left(\mathrm{mg}\right.$ GAE $\left.100 \mathrm{~g}^{-1}\right)$.

The determination of TAA was based on decrease in absorption by 2,2-diphenyl-1-picryl hydrazyl radical (DPPH; 60 $\mu \mathrm{M})$ as described by RUFINO et al. (2007), with some modifications. To each extract of pepper sample $(0.4 \mathrm{~mL})$, DPPH radical $(60 \mu \mathrm{M} ; 1.6 \mathrm{~mL})$ was added. After incubation (30min), the absorbance was read on a UV-visible spectrophotometer $(\lambda=515 \mathrm{~nm})$. Absorbance values were converted into \% AA using the following equation, \% Inhibition $=100 *\left(\mathrm{~A}_{\text {Control }}-\mathrm{A}_{\text {Extract }}\right) /$ $\mathrm{A}_{\text {Control }}$, where $\mathrm{A}=$ Absorbance.

Data were submitted to analysis of variance and the means were compared (Tukey's test; $\mathrm{P}<0.05$ ) using the SAS (SAS INSTITUTE INC.).

\section{RESULTS AND DISCUSSION}

The SS content of "dedo-de-moça" 'BRS Mari' pepper fruits increased until 70 DAA, remaining constant until 80 DAA (Table 1). The increase observed in the SS content may be due to dissociation of some structural organic molecules in soluble compounds (TSEGAY et al., 2013). In this study (70 DAA), the values were higher than those reported in the study by FERRÃO et al. (2011), who obtained variations in the range $5.5-11.9^{\circ}$ Brix in the values for SS in samples from Capsicum baccatum fruits in mature stage.

The values for TA were higher in fruits harvested at 50 DAA, although they did not differ from those obtained in fruits harvested at 60 and 70 DAA. In addition, they were lower in fruits harvested until 40 DAA and at 80 DAA (Table 1).
These results are in agreement with those obtained by TSEGAY et al. (2013), who reported higher values for TA in Capsicum annuum L. varieties. Their fruits had $50 \%$ of the epidermis with red color, which reduced with the progress of ripening. The increase in the values for TA may be due to the activity of the pectinmethylesterase enzyme, whereas reduction in the values for TA in fruits harvested after 50 DAA may be due to their elevated respiratory rate (ANTHON \& BARRETT, 2012).

In mature fruits (70 and 80 DAA), the $\mathrm{SS} / \mathrm{TA}$ ratio was greater than in fruits harvested in the stages (Table 1). This result is mainly explained by the SS content, which was higher in fruits harvested 70 and $80 \mathrm{DAA}$. The SS/TA ratio is used as an indicator of palatability. An increase in this ratio may be associated with a more pleasant taste and indicate that the fruit has ripened (SOARES JÚNIOR et al., 2008).

The $a$ and total chlorophyll contents reduced until 60 DAA, when the fruits had a fully red external color. The values for $b$ chlorophyll were higher until 30 DAA and decreased thereafter (Table 2). During fruit ripening, degradation in a chlorophyll is generally more intense than in $b$ chlorophyll, since $\mathrm{b}$ chlorophyll has to be converted to a chlorophyll to enter the degradative route (MATILE et al., 1996). This reduction indicates a change in the fruit development phase during catabolism of these pigments. This can be explained by change in $\mathrm{pH}$ and efficiency in the action of the chlorophyllase enzyme (SENTHILKUMAR \& VIJAYAKUMAR, 2014).

The lightness parameter decreased in the period 40-60 DAA (Table 2). The lightness values

Table 1 - Mean values for soluble solids content (SS), titratable acidity (TA), and SS/TA ratio of "dedo-de-moça" 'BRS Mari' pepper fruits harvested in different stages of maturation (SM).

\begin{tabular}{llll}
\hline SM (DAA) & SS $\left({ }^{\circ}\right.$ Brix $)$ & TA $(\%)$ & SS/TA \\
\hline 20 & $6.6 \mathrm{~d}^{*}$ & $0.36 \mathrm{bc}$ & $18.3 \mathrm{~d}$ \\
30 & $7.1 \mathrm{~d}$ & $0.31 \mathrm{c}$ & $22.8 \mathrm{~cd}$ \\
40 & $8.5 \mathrm{c}$ & $0.31 \mathrm{c}$ & $27.9 \mathrm{~b}$ \\
50 & $9.5 \mathrm{c}$ & $0.49 \mathrm{a}$ & $19.4 \mathrm{~d}$ \\
60 & $11.8 \mathrm{~b}$ & $0.44 \mathrm{ba}$ & $26.8 \mathrm{cb}$ \\
70 & $14.3 \mathrm{a}$ & $0.44 \mathrm{ba}$ & $32.7 \mathrm{a}$ \\
80 & $13.7 \mathrm{a}$ & $0.37 \mathrm{bc}$ & $37.1 \mathrm{a}$ \\
$\mathrm{CV}(\%)$ & 3.35 & 7.64 & 6.14 \\
\hline
\end{tabular}

*Values that are not followed by the same letter are statistically different from others in the column (Tukey test; P<0.05). CV: coefficients of variation. 
Table 2 - Mean values for contents of $a, b$, and total chlorophyll and color properties (lightness and hue angle) of "dedo-de-moça” 'BRS Mari' pepper fruits harvested at different stages of maturation (SM).

\begin{tabular}{|c|c|c|c|c|c|}
\hline SM (DAA) & Chlorophyll $a\left(\mathrm{mg} \mathrm{kg}^{-1}\right)$ & Chlorophyll $b\left(\mathrm{mg} \mathrm{kg}^{-1}\right)$ & Total chlorophyll (mg kg-1) & Lightness & Hue angle \\
\hline 20 & $5.4 \mathrm{a}^{*}$ & $2.5 \mathrm{a}$ & $7.8 \mathrm{a}$ & $63.9 \mathrm{a}$ & $110.0 \mathrm{a}$ \\
\hline 30 & $2.2 \mathrm{~b}$ & $2.0 \mathrm{a}$ & $4.3 \mathrm{~b}$ & $63.8 \mathrm{a}$ & $106.4 \mathrm{~b}$ \\
\hline 40 & $1.1 \mathrm{c}$ & $1.0 \mathrm{~b}$ & $2.1 \mathrm{c}$ & $63.7 \mathrm{a}$ & $99.5 \mathrm{c}$ \\
\hline 50 & $0.9 \mathrm{c}$ & $0.9 \mathrm{~b}$ & $1.8 \mathrm{c}$ & $48.1 \mathrm{~b}$ & $55.2 \mathrm{~d}$ \\
\hline 60 & $0.2 \mathrm{~d}$ & $0.4 \mathrm{~b}$ & $0.6 \mathrm{~d}$ & $36.4 \mathrm{c}$ & $28.7 \mathrm{e}$ \\
\hline 70 & $0.2 \mathrm{~d}$ & $0.4 \mathrm{~b}$ & $0.5 \mathrm{~d}$ & $35.4 \mathrm{c}$ & $28.0 \mathrm{e}$ \\
\hline 80 & $0.2 \mathrm{~d}$ & $0.4 \mathrm{~b}$ & $0.5 \mathrm{~d}$ & $34.5 \mathrm{c}$ & $26.7 \mathrm{e}$ \\
\hline $\mathrm{CV}(\%)$ & 13.48 & 31.51 & 15.71 & 1.60 & 1.51 \\
\hline
\end{tabular}

${ }^{*}$ Values that are not followed by the same letter are statistically different from others in the column (Tukey test; $\left.\mathrm{P}<0.05\right)$. CV: coefficients of variation.

are influenced by changes in fruit color. In this period, the fruits changed their external color, going from green (40 DAA) to orange (50 DAA) and red (60 DAA). According to CABRAL et al. (2010), a mass loss occurs during maturation of pepper fruits due to a decrease in water content that occurs by transpiration. Such changes may cause a decrease in the lightness values.

The hue angle values were in the first and second quadrants $\left(0^{\circ}\right.$ and $\left.180^{\circ}\right)$ since the pericarp color evolved from green to red, thus causing a decrease in the hue angle values until 60 DAA and little change until 80 DAA (Table 2). RAHMAN et al. (2014) showed that the hue angle decreased with progress in ripening of Capsicum annumm L. fruits, as shown in this study. The change in color (green to red) of the pepper fruit epidermis during maturation is related to the processes of degradation of chlorophyll pigments and synthesis of carotenoid pigments (yellow, orange, and red), which occur during fruit development (SENTHILKUMAR \& VIJAYAKUMAR, 2014).

The content of TPC in pepper fruits increased until 60 DAA, and little variation occurred since then until 80 DAA (Figure 1A). At 80 DAA, the content of TPC was $76 \%$ higher than that in fruits harvested at 20 DAA. This observation confirms the result of CASTROCONCHA et al. (2014), who reported an increase in the content of TPC with progress in maturation. COSTA et al. (2009) found that the concentration of TPC in extracts of Capsicum baccatum var. praetermissum pepper fruits (cumari) was $177.7 \mathrm{mg}$ GAE $100 \mathrm{~g}^{-1}$ in mature fruits. The presence of phytochemicals, such as TPC, in plants is influenced by genetic factors, environmental conditions, and maturation stage (NADEEM et al., 2011; PINTO et al., 2013).

TAA in pepper fruits increased with progress in their maturation (Figure 1B). The percent inhibition of free radicals at 80 DAA was $48 \%$ higher than that in fruits harvested at 20 DAA. SAIDU \& GARBA (2011) obtained 78.4 (red), 67.1 (yellow), and $36.5 \%$ (green) TAA of pepper fruits in Capsicum frutescens. Results of this study are in agreement with those of CASTRO-CONCHA et al. (2014), who studied the effect of maturation on the antioxidant content in Capsicum chinense Jacq. and reported that TAA increased with progress in fruit ripening.

TPC are bioactive compounds that contribute to the antioxidant potential in vegetables (SAIDU \& GARBA, 2011; PINTO et al., 2013). Studies in extracts show a correlation between the content of TPC and TAA (SAIDU \& GARBA, 2011; CASTRO-CONCHA et al., 2014), indicating that the TAA is due to the presence of phenolic compounds. The TAA of TPC is mainly due to their redox properties, which allow them to act as reducing agents, hydrogen donors, and singlet oxygen suppressors (AIYEGORO \& OKOH, 2009). However, the TAA did not follow the same tendency of the TPC present in fruits. This can be observed in the present study, in which a substantial increase in TPC occurred until 60 DAA (Figure 1A), whereas the increase in TAA occurred until 80 DAA (Figure 1B). This occurs because the antioxidant agent in the TPC depends on the structure, especially the number and position of 


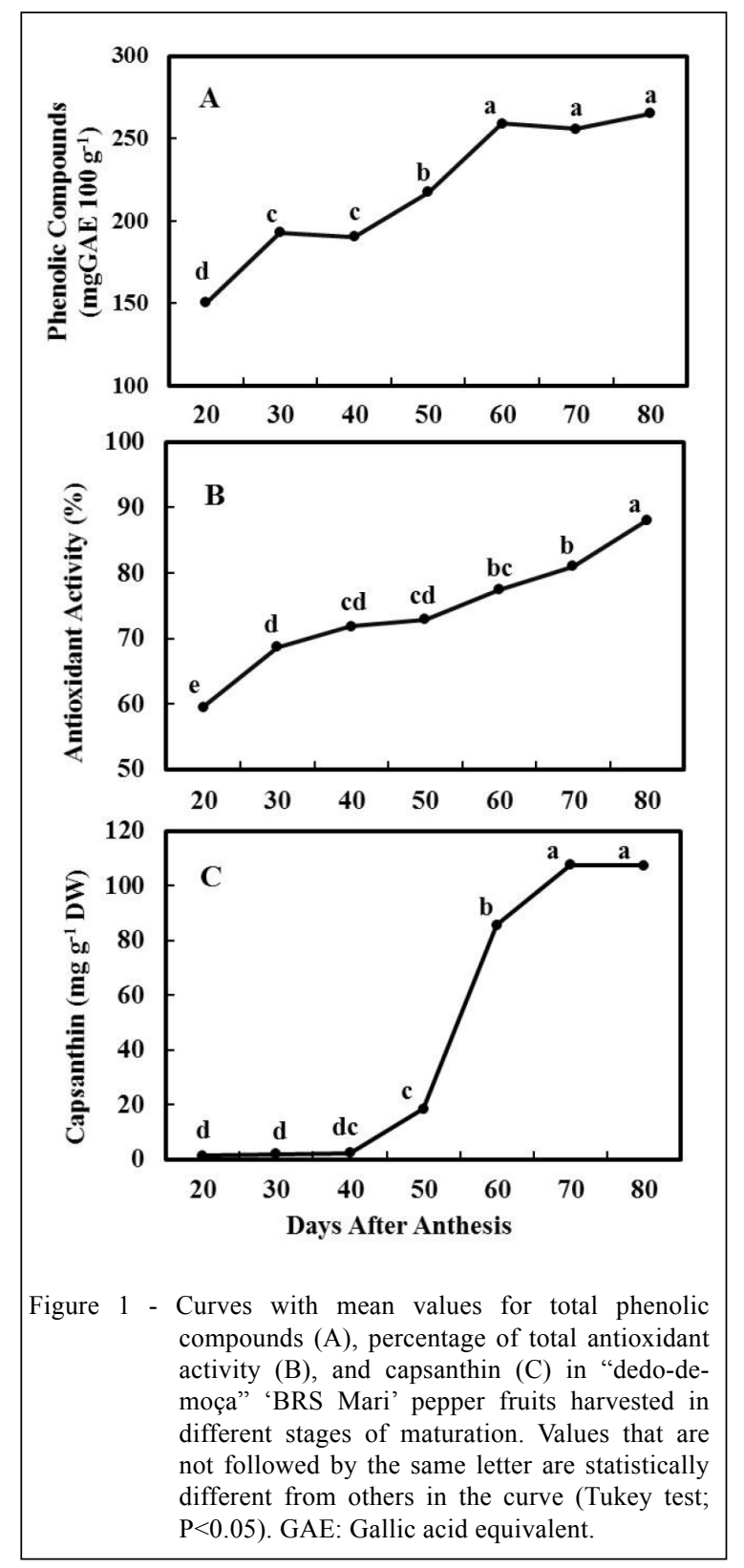

hydroxyl groups and nature of substitutions in the aromatic rings. In this sense, the differences are attributed to the specific structure and concentration of each compound (QUIRÓS-SAUCEDA et al., 2014). However, the antioxidant properties may be due to other phytochemicals present in the extract, such as carotenoids, vitamins, and capsaicinoids (CASTRO-CONCHA et al., 2012).

An increase was observed in the capsanthin content until 70 DAA, when the external color of the fruit was completely red. For fruits with green epidermis harvested in the period 20-40 DAA, the capsanthin concentration was low, compared with concentrations in the following stages (Figure 1C). This result is in agreement with those of GUZMAN et al. (2010). These authors cite that capsanthin is synthesized during maturation and their highest content occurs in fruits with red color. According to GÓMEZ-GARCÍA \& OCHOA-ALEJO (2013), the capsanthin levels increased and the pigment becomes more liposoluble during maturation of the pepper fruit because their hydroxyl groups are esterified with fatty acids. These carotenoids, which are more lipophilic, are easily incorporated into chromoplasts increasing the red color of fruits. According to NADEEM et al. (2011), capsanthin howed to be important in scavenging free radicals, due to its efficient antioxidant action, which may partly responsible for the increase in the TAA until 80 DAA.

\section{CONCLUSION}

After anthesis, the soluble solids content increased until 70 days and the value for titratable acidity increased until 50 days, decreasing in the following stages. The value for the soluble solids/ titratable acidity ratio increased until 70 days after anthesis. A change occurred in the color of pepper fruits with progress in the maturation stage until 60 days after anthesis. A decrease was observed in the content of chlorophylls, especially chlorophyll $a$, and synthesis of the capsanthin carotenoid with progress in maturation. In relation to the total content of phenolic compounds, an increase was observed until 60 days after anthesis. This and the increase the capsanthin content may have caused an increase in antioxidant activity with progress in maturation. Antioxidant activity increased until 80 days after anthesis, with no change in the other characteristics. The ideal maturation stage for fruit harvest occurred at 70 days after anthesis, when maximum levels were observed for soluble solids, soluble solids/titratable acidity ratio, and total phenolic compounds, in addition to full development of red color in the fruit epidermis.

\section{ACKNOWLEDGEMENTS}

Coordenação de Aperfeiçoamento de Pessoal de Nível Superior (CAPES) for granting scholarships, the Universidade do Estado de Santa Catarina (UDESC), and Embrapa Hortaliças by financial support. 


\section{REFERENCES}

AIYEGORO, O.A.; OKOH, A.I. Phytochemical screening and polyphenolic antioxidant activity of aqueous crude leaf extract of Helichrysum pedunculatum. International Journal of Molecular Sciences, v.10, n.11, p 4990-5001, 2009. Available from: <http://www.mdpi.com/14220067/10/11/4990>. Accessed: Nov 12, 2014. doi: 10.3390/ ijms 10114990 .

ANTHON, G.E; BARRETT, D.M. Pectin methylesterase activity and other factors affecting $\mathrm{pH}$ and titratable acidity in processing tomatoes. Food Chemistry, v.132, p.915-920, 2012. Available from: <http:/ucce.ucdavis.edu/files/datastore/234-2155.pdf> Accessed: Dec 09, 2014.

CABRAL, V.O.S. et al. Water relations and rehydration of hot pepper fruits (Capsicum spp.). Magistra, v.22, n.2, p.83-87, 2010 Available from: <https://www.ufrb.edu.br/frutos-de-pimentacapsicum-spp>. Accessed: Oct 25, 2014.

CASTRO-CONCHA, L.A. et al. Determination of antioxidants in fruit tissues from three accessions of habanero pepper (Capsicum chinense Jacq.). Journal of Mexican Chemical Society, v.56, n.1, p.15-18, 2012. Available from: <http:// www.scielo.org.mx/pdf/jmcs/v56n1/v56n1a4.pdf $>$. Accessed: Oct 16, 2014.

CASTRO-CONCHA, L.A. et al. Antioxidant capacity and total phenolic content in fruit tissues from accessions of Capsicum chinense Jacq. (Habanero Pepper) at different stages of ripening. Scientific World Journal, v.2014, p.1-5, 2014. Available from: <http://dx.doi. org/10.1155/2014/809073>. Accessed: Nov 10, 2014. doi: $10.1155 / 2014 / 809073$.

CAVALCANTE, T.R.M. Pollination and fruit development in araticum. Bragantia, v.68, n.1, p.13-21, 2009. Available from: $<$ http://www.scielo.br/pdf/brag/v68n1/a02v68n1.pdf $>$. Accessed: Nov 16, 2014.

COSTA, L.M. et al. Antioxidant activities of peppers of the genus Capsicum. Ciência e Tecnologia de Alimentos, v.30, n.1, p.5159, 2009. Available from: <http://dx.doi.org/10.1590/S010120612009005000004>. Accessed: Nov 01, 2014. doi: 10.1590/ S0101-20612009005000004.

FERRÃO, L.F.V. et al. Genetic divergence among subsamples of pepper based on morpho-agronomic characters. Horticultura Brasileira, v.29, n.3, p.354-358, 2011. Available from: <http://dx.doi.org/10.1590/S010205362011000300016>. Accessed: Oct 16, 2014. doi: 10.1590/ S0102-05362011000300016.

GÓMEZ-GARCÍA, M.D.R.; OCHOA-ALEJO, N. Biochemistry and molecular biology of carotenoid biosynthesis in chili peppers (Capsicum spp.). International Journal Molecular Sciences, v.14, n.9, p.19025-19053, 2013. Available from: <http://www. mdpi.com/1422-0067/14/9/19025>. Accessed: Nov 25, 2014. doi: $10.3390 /$ ijms 140919025 .

GUZMAN, I. et al. Variability of carotenoid biosynthesis in orange colored Capsicum spp. Plant Science, v.179, n.1-2, p.4959, 2010. Available from: <http://www.ncbi.nlm.nih.gov/pmc/ articles/PMC2889374/>. Accessed: Nov 19, 2014. doi: 10.1016/j. plantsci.2010.04.014
MATILE, P. et al. Chlorophyll breakdown in senescent leaves. Plant Physiology, v.112, n.4, p.1403-1409, 1996. Available from: <http://www.plantphysiol.org/content/112/4/1403.full.pdf>. Accessed: Nov 16, 2014.

MATTOS, L.M. et al. Protocolos de avaliação da qualidade química e física de pimentas (Capsicum sp.). Brasília: Embrapa Hortaliças, 2007. 9p. (Comunicado Técnico, n.50). Available from: <http://ainfo.cnptia.embrapa.br/digital/ bitstream/cnph-2010/34565/1/cot-50.pdf $>$. Accessed: Nov $18,2014$.

NADEEM, M. et al. Antioxidant potential of bell pepper (Capsicum annum L.) a review. Pakistan Journal of Food Science, v.21, n.14, p.45-51, 2011. Available from: <https://www.researchgate.net/ publication/255969817>. Accessed: Oct 19, 2014.

PINTO, C.M.F. et al. Pimenta Capsicum: propriedades químicas, nutricionais, farmacológicas e medicinais e seu potencial para o agronegócio. Revista Brasileira de Agropecuária Sustentável, v.3, n.2, p.108-120, 2013. Available from: <http:// www.rbas.com.br/index.php/rbas/article/view/225>. Accessed: Oct 19, 2014

QUIRÓS-SAUCEDA, A.E. et al. Added dietary fiber affects antioxidant capacity and phenolic compounds content extracted from tropical fruit. Journal of Applied Botany and Food Quality, v.87, p.227-233, 2014. Available from: <http://pub.jki.bund.de/ index.php/ jabfq/article/view/2825>. Accessed: Nov 01, 2014. doi: $0.5073 /$ jabfq.2014.087.032.

RAHMAN, M.A. et al. Changes in physicochemical atributes of sweet pepper (Capsicum annum L.) during fruit growth and development. Journal of Agricultural Research, v.39, n.2, p.373-383, 2014. Available from: <http://www.banglajol.info/ index.php/bjar/article/ viewFile/20446/14141>. Accessed: Nov 19, 2014.

RODRÍGUEZ-MATURINO, A. et al. Antioxidant activity and bioactive compounds of chiltepín (Capsicum annuum var. Glabriusculum) and Habanero (Capsicum chinense): a comparative study. Journal of Medicinal Plants Research, v.6, n.9, p.1758-1763, 2012. Available from: <http://www. academicjournals.org/jmpr>. Accessed: Dec 09, 2014. doi: $10.5897 /$ jmpr 11.1576 .

ROESLER, R. et al. Antioxidant activity of cerrado fruits. Ciência e Tecnologia de Alimentos, v.27, n.1, p.53-60, 2007. Available from: <http://dx.doi.org/10.1590/S010120612007000100010>. Accessed: Apr 23, 2014. doi: 10.1590/ S0101-20612007000100010.

RUFINO, M.S.M. et al. Metodologia científica: determinação da atividade antioxidante total em frutas pela captura do radical livre DPPH. Fortaleza: Embrapa, 2007. 4p. (Comunicado técnico, n.127). Available from: <https://www.embrapa.br/agroindustriatropical/publicacoes $>$. Accessed: Apr 28, 2014.

SAIDU, A.N.; GARBA, R. Antioxidant activity and phytochemical screening of five species of Capsicum fruits. International Research Journal of Biochemistry and Bioinformatics, v.1, n.9, p.237-241, 2011. Available from: <http://www.interesjournals.org/ irjbb>. Accessed: Oct 25, 2014.

SENTHILKUMAR, S.; VIJAYAKUMAR, R.M. Biochemical, physiological and horticultural perspectives of fruit colour 
pigmentation: a review. Research and Reviews: Journal of Agriculture and Allied Sciences, v.3, n.1, p.9-16, 2014 Available from: <http://www.rroij.com/open-access/biochemicalphysiological-and-horticultural-perspectives-of-fruit-colourpigmentation-a-review.php?aid=33838> . Accessed: Nov 11, 2014.

SOARES JÚNIOR, M. et al. Postharvest conservation of mangaba fruit as a function of maturity, atmosphere, and storage temperature. Pesquisa Agropecuária Tropical, v.38, n.2, p.7886, 2008. Available from: <http://dx.doi.org/10.1590/S0101-
20612009000100014>. Accessed: June 25, 2015. doi: 10.1590/ S0101-20612009000100014.

TSEGAY, D. et al. Effects of harvesting stage and storage duration on postharvest quality and shelf life of sweet bell pepper (Capsicum annuum L.) varieties under passive refrigeration system. International Journal for Biotechnology and Molecular Biology Research, v.4, n.7, p.98-104, 2013. Available from: <http://www.academicjournals.org/ijbmbr>. Accessed: Nov 09, 2014. doi: 10.5897/ijbmbr2013.0154.

Ciência Rural, v.46, n.8, ago, 2016. 